University of Nebraska - Lincoln

DigitalCommons@University of Nebraska - Lincoln

2013

\title{
Introduced northern pike predation on salmonids in southcentral alaska
}

Adam J. Sepulveda

U.S. Geological Survey, asepulveda@usgs.gov

David S. Rutz

Alaska Department of Fish and Game

Sam S. Ivey

Alaska Department of Fish and Game

Kristine J. Dunker

Alaska Department of Fish and Game

Jackson A. Gross

U.S. Geological Survey

Follow this and additional works at: https://digitalcommons.unl.edu/usgsstaffpub

Sepulveda, Adam J.; Rutz, David S.; Ivey, Sam S.; Dunker, Kristine J.; and Gross, Jackson A., "Introduced northern pike predation on salmonids in southcentral alaska" (2013). USGS Staff -- Published Research. 720.

https://digitalcommons.unl.edu/usgsstaffpub/720

This Article is brought to you for free and open access by the US Geological Survey at DigitalCommons@University of Nebraska - Lincoln. It has been accepted for inclusion in USGS Staff -- Published Research by an authorized administrator of DigitalCommons@University of Nebraska - Lincoln. 


\title{
Introduced northern pike predation on salmonids in southcentral alaska
}

\author{
Adam J. Sepulveda ${ }^{1}$, David S. Rutz ${ }^{2}$, Sam S. Ivey ${ }^{2}$, Kristine J. Dunker ${ }^{3}$, Jackson A. Gross ${ }^{1}$ \\ ${ }^{1}$ US Geological Survey, Northern Rocky Mountain Science Center, 2327 University Way,Suite 2, Bozeman, MT 59715, USA \\ ${ }^{2}$ Alaska Department of Fish \& Game, Division of Sport Fish, Palmer, AK 99645, USA \\ ${ }^{3}$ Alaska Department of Fish \& Game, Division of Sport Fish, Anchorage, AK 99518, USA
}

Accepted for publication November 27, 2012

\begin{abstract}
Northern pike (Esox lucius) are opportunistic predators that can switch to alternative prey species after preferred prey have declined. This trophic adaptability allows invasive pike to have negative effects on aquatic food webs. In Southcentral Alaska, invasive pike are a substantial concern because they have spread to important spawning and rearing habitat for salmonids and are hypothesised to be responsible for recent salmonid declines. We described the relative importance of salmonids and other prey species to pike diets in the Deshka River and Alexander Creek in Southcentral Alaska. Salmonids were once abundant in both rivers, but they are now rare in Alexander Creek. In the Deshka River, we found that juvenile Chinook salmon (Oncorhynchus tshawytscha) and coho salmon $(O$. kisutch $)$ dominated pike diets and that small pike consumed more of these salmonids than large pike. In Alexander Creek, pike diets reflected the distribution of spawning salmonids, which decrease with distance upstream. Although salmonids dominated pike diets in the lowest reach of the stream, Arctic lamprey (Lampetra camtschatica) and slimy sculpin (Cottus cognatus) dominated pike diets in the middle and upper reaches. In both rivers, pike density did not influence diet and pike consumed smaller prey items than predicted by their gape-width. Our data suggest that (1) juvenile salmonids are a dominant prey item for pike, (2) small pike are the primary consumers of juvenile salmonids and (3) pike consume other native fish species when juvenile salmonids are less abundant. Implications of this trophic adaptability are that invasive pike can continue to increase while driving multiple species to low abundance.
\end{abstract}

Key words: Alaska; diet; Esox lucius; Northern pike; prey-specific abundance; salmon; Susitna River

\section{Introduction}

The introduction and spread of nonnative species are altering aquatic and terrestrial communities worldwide. In particular, opportunistic predators that invade have had catastrophic effects on native biota (Ogutu-Ohwayo 1990), food web structure (Vander Zanden et al. 1999) and ecosystem function (Baxter et al. 2004) because alternative prey species can support the predator population after preferred prey have declined. Thus, predators can continue to increase and spread while eliminating native species (OgutuOhwayo 1990; Albins \& Hixon 2008).

Northern pike (Esox lucius) are opportunistic predators that have been introduced into freshwater systems across the globe and have been linked to the decline and elimination of multiple fish species (e.g., Patankar et al. 2006; Byström et al. 2007; Johnson et al. 2008). Pike are ambush predators that require slow-moving, shallow vegetated waters for spawning, rearing and foraging (Casselman \& Lewis 1996). They prefer soft-rayed fish, but are trophically adaptable and will switch to spiny-rayed fish, invertebrates and cannibalism when preferred prey are at low densities (Eklöv \& Hamrin 1989).

In the Susitna River basin of Southcentral Alaska, shallow vegetated lakes and sloughs are common features that serve as critical rearing habitats for numerous soft-rayed fish species, particularly salmonids. Pike were introduced into Southcentral Alaska in the 1950 's and have since spread to $>100$ lakes and 70 drainages within the Susitna basin (Rutz 1999). The 
expansion of pike is hypothesised to be a leading cause for the decline of multiple salmonid species in streams that once supported popular sport fisheries (Rutz 1999; Patankar et al. 2006). The economic and cultural costs of salmonid declines are considerable, as sport and commercial fisheries for salmon have been closed or restricted in systems where pike have established. Pike consumption of salmonids may also have severe ecological consequences because salmon are keystone species that provide food and nutrients to aquatic and terrestrial ecosystems (Cederholm et al. 1999).

We described the diet of pike in two tributaries of the Susitna River basin, the Deshka River and Alexander Creek. Our objectives were to (1) assess the relative importance of salmonids to the diet of pike, (2) assess how pike consumption of salmonids differ across space and time and (3) identify other native fish species that are vulnerable to pike predation. To make inferences about the importance of salmonids to the diet of pike, we sampled pike in the Deshka River because it has multiple salmonid populations that still meet Sustainable Escapement Goals (the number of spawning salmon required for sustaining fisheries). To make inferences about the impact of pike on other prey fish after salmonids have declined, we sampled pike in Alexander Creek because escapement estimates for the last decade have shown a downward trend in Chinook salmon (Oncorhynchus tshawytscha) abundance and a decline in sport harvest and catch trends for other salmonid species.

\section{Methods}

\section{Study sites}

The Susitna River basin originates from two major mountain ranges (Talkeetna and Alaska) and generally flows in a southerly direction before emptying into Upper Cook Inlet (Fig. 1). The basin has hundreds of shallow lakes and ponds, sloughs and side channels with large beds of aquatic vegetation, and thousands of square kilometres of adjacent interconnecting wetland areas that are ideal spawning and rearing habitats for pike. We sampled two streams in the Susitna River basin: the Deshka River and Alexander Creek (Fig. 1).

The Deshka River flows approximately $225 \mathrm{~km}$ from the headwaters just south of Denali National Park to the confluence with the Susitna River. Channel width varies from $91 \mathrm{~m}$ at the mouth to approximately $30 \mathrm{~m}$ upstream. The average discharge at the mouth is $25 \mathrm{~m}^{3} \cdot \mathrm{s}^{-1}$. The lowest section of the Deshka has few slow-moving, sloughs and side channels, and the main channel provides little pike habitat because it is deeper, has high velocity and is domi- nated by mid-channel gravel bars and riffles. Pike were first recorded in 1983, but age analyses of these fish suggest that they were introduced into the Deshka River around 1970 (unpublished data, D. Rutz). Area anglers did not capture large numbers and multiple age classes of pike until the early 1990s (Whitmore \& Sweet 1998). The Sustainable Escapement Goal for Chinook salmon is 13,000-28,000 fish and escapement counts have ranged between 7,533 and 37,725 since 2005 (Oslund \& Ivey 2010). Given that salmonids remain abundant in the Deshka River, we sampled pike from this location to describe the contribution of salmonids to pike diets.

Alexander Creek flows 64 kilometres from Alexander Lake to the confluence with the Susitna River. The main stem is surrounded with numerous sidechannel sloughs. A large portion of the mainstem and the sloughs are shallow $(<1.5-\mathrm{m}$ deep), low gradient and densely vegetated. Most of the creek flows through large, adjacent interconnecting wetland areas that remain flooded throughout most of the spring, which coincides with the pike spawning migration. Summer discharge is around $7.7 \mathrm{~m}^{3} \cdot \mathrm{s}^{-1}$. Pike were introduced to Alexander Lake in the late 1960s, although there is no harvest record of pike prior to 1985 (Mills 1985). Today, pike are widespread throughout the system. Pike are hypothesised to be primary drivers of declines in multiple fish species beginning in the late 1990s including Chinook, coho (O. kisutch), chum (O. keta) and sockeye (O. nerka) salmon, rainbow trout (O. mykiss) and Arctic grayling (Thymallus arcticus) (Rutz 1999). For example, average escapements for Chinook salmon from 1979 through 1999 were 3500 fish while escapement from 2000 through 2008 was 1600 fish. In 2010, counts declined to 177 fish (Oslund \& Ivey 2010). The rainbow trout and grayling fisheries were closed to harvest in 1996 and the Chinook salmon sport fishery was closed in 2008. As salmonid stocks are currently at such low levels in Alexander Creek, this location offered an opportunity to study the dietary patterns of pike on nonsalmonid taxa.

\section{Fish capture \& handling}

In the Deshka River, we used gill nets $(2.5-\mathrm{cm}$ bar mesh) to capture pike in five side-channel sloughs. Pike $>370 \mathrm{~mm}$ (fork length, FL) were captured by their teeth or entangled, and pike $<350 \mathrm{~mm}$ were often gilled. We fished five gill nets per slough for three, $90-$ min sets. The same five sloughs were sampled in spring (May 17-21 $1^{\text {st }}$ ), summer (June 26-30 ${ }^{\text {th }}$ ) and early fall (August $26^{\text {th }}-29^{\text {th }}$ ).

In Alexander Creek, Alaska Department of Fish \& Game (ADFG) began a gill netting operation to remove pike in side-channel sloughs of the upper, 


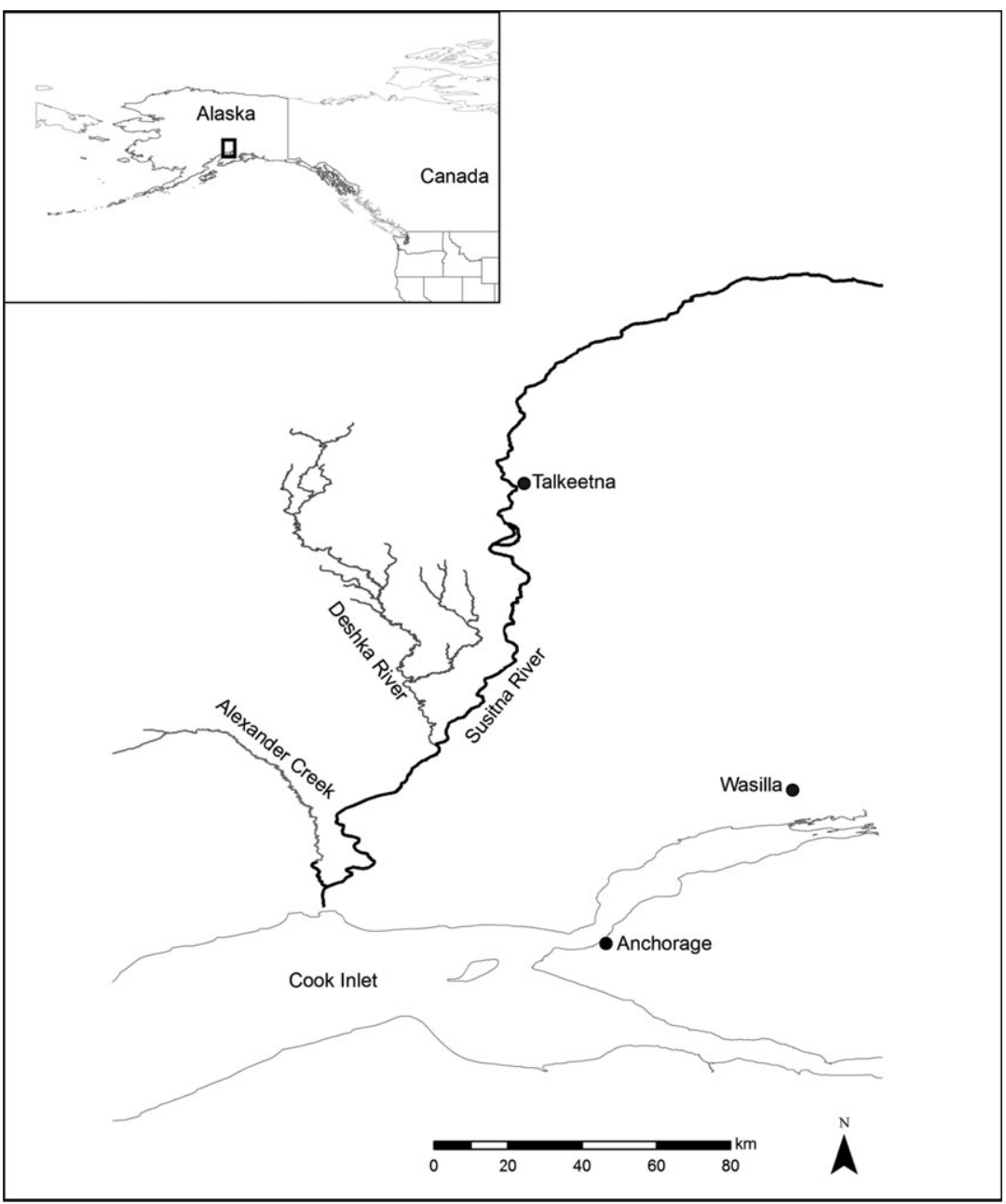

Fig. 1. Map of Alexander Creek and the Deshka River in the Susitna River basin.

middle and lower reaches in May 2011. Up to six experimental-mesh gill nets (six, 6-m panels of $1.9-\mathrm{cm}$, $2.5-\mathrm{cm}, 3.2-\mathrm{cm}, 3.8-\mathrm{cm}, 4.4-\mathrm{cm}, 5-\mathrm{cm}$ bar mesh) were fished in each slough and checked every $24 \mathrm{~h}$ and all captured pike were euthanised. Sloughs were fished until an $85 \%$ reduction in pike catch was achieved. We sampled pike from five sloughs in each reach during the late spring (May 13-15 $5^{\text {th }}$ ) and five sloughs in the upper reach in summer (June 20-24 ${ }^{\text {th }}$ ). The remoteness of Alexander Creek, desiccation of sloughs and logistical difficulties prevented sampling in lower and middle reaches in June and all sites in August.

All fish were measured for length (FL; mm) and weight $(\mathrm{g})$. We used gastric lavage to obtain stomach contents from pike captured in the Deshka River and we removed entire stomachs from fish that were captured in Alexander Creek. Five pike from each Deshka River slough were dissected to verify that gastric lavage removed all stomach contents. Stomachs and stomach contents were preserved in 95\% ethanol until identification. To ensure that no fish was sam- pled $>1$ time per sampling period in the Deshka River, we inserted floy-tags into the base of the dorsal fin of pike before releasing them near the capture location.

Stomach contents were identified by trained technicians at Rhithron Associates, Inc. (Missoula, MT). Prey fish were identified to species when possible, and invertebrates were identified to the lowest practical taxonomic level. We excluded contents that could not be identified in analyses. All prey items were identified, enumerated and measured for length and weighed (blotted wet weight).

\section{Data analysis}

To compare pike diets across time and space, we conducted two analyses. First, we assessed the proportion of Pacific salmonids in pike diets relative to the other prey taxa. For this analysis, we grouped all taxa that belonged to the Oncorhynchus genus (coho, Chinook, and sockeye salmon and rainbow trout) into the Total Oncorhynchus category. Second, we 
assessed the proportion of each individual Oncorhynchus species in pike diets. Many samples could not be identified beyond the genus Oncorhynchus, so we placed these samples into the prey category, 'unidentified Oncorhynchus spp'.

For each prey category, we calculated the per cent occurrence $(\% O)$, per cent by number $(\% N)$ and per cent by mass $(\% M)$ according to Chipps \& Garvey (2007). We also calculated the prey-specific abundance (PSA) for each prey item (i) as follows:

$$
P S A_{i}=100 \times \frac{\sum S_{i}}{\sum S_{t i}}
$$

where $S_{i}$ equals the wet weight of prey $i$ in stomachs, and $S_{t i}$ equals the total wet mass of prey in predators that contain prey $i$.

We used multivariate analysis of covariance (MANCOVA) to test for an overall season effect (May vs. June vs. August) on diet composition in the Deshka River and for an overall reach effect in Alexander Creek (lower vs. middle vs. upper in May vs. upper in June). We used $\% M$ for each prey taxa as our response variable and pike length as our covariate. The interaction terms of season $\times$ pike length and reach $\times$ pike length were not significant, so only main effects are reported. The mass of prey items is a useful metric for predator-prey studies because it is measured in units that can be compared to other studies and can be used to compare the energetic importance of different prey types (Chipps \& Garvey 2007). To test if the mass of consumed prey types varied among and within seasons in the Deshka River and among and within reaches in Alexander Creek, we used analysis of covariance (ANCOVA) with\%M of each prey taxa as our response variable and pike length as our covariate. As these tests were a posteri, we set appropriate alpha levels using the Bonferroni inequality overall alpha divided by $n$ (e.g., the number of seasons or reaches). We used the Tukey Honest Significance Difference (HSD) test as a post-hoc test to identify the prey items with the highest $\% M$. To satisfy assumptions of normality, we arcsinesquare root transformed $\% M$ when necessary. We report all means using the untransformed, least-square means ( $\pm 1 \mathrm{SE})$.

To explore patterns of relative prey importance, we constructed bivariate plots of $P S A$ versus\%O. Dominant prey items have high $\% O$ in the diets and high PSA values, while rare prey items have low PSA and low\% $O$ values. Opportunistic feeding is represented for prey items that have high PSA and low\%O in the diets, and generalised feeding is characterised by prey items that have low PSA and high\%O. When plotted in this fashion, graphical techniques can be used to evaluate relative prey dominance and the degree of homogeneity of the diet (Amundsen et al. 1996; Chipps \& Garvey 2007).

Pike density can affect diet due to interactions among predators (e.g., kleptoparasitism and cannibalism; Nilsson \& Brönmark 1999). Pike at high densities select different prey items and have decreased intake rates than pike at low densities (Nilsson 2001). To assess density effects on diet, we examined the relationships between pike relative abundance and the prey category with the greatest $\% M$ in each sampled slough in the Deshka River and Alexander Creek. In the Deshka River, we estimated pike relative abundance per slough as the total number of unique pike caught in all three gill net sets. In Alexander Creek, we used the total number of pike captured in each sampled slough to estimate relative abundance. We ran separate analyses for each stream because gill net capture effort differed. We also analysed the three Alexander Creek reaches separately because effort differed (i.e., each reach was sampled by a different field crew).

Pike diet can also be limited by gape size, which is a linear function of pike body length (Nilsson \& Brönmark 2000). To test if pike diet is better predicted by prey size than by prey identity, we tested for correlations between the maximum length of prey items in each pike sample and pike length. All statistical analyses were performed in JMP 9.0.2 (SAS Institute, Carey, North Carolina, United States).

\section{Results}

\section{Deshka River}

Pike sample size and lengths are reported in Table 1. Pike length differed across our sampling dates (ANOVA: $F_{2,216}=13.26, P=<0.0001$ ). Pike sampled in May and August were of similar length and were larger than pike sampled in June (Tukey-HSD). Gastric lavage removed $96 \%( \pm 3 \%)$ of the total mass of stomach contents $(n=25)$. We observed 14 species of fish, 6 types of invertebrates, 1 anuran and 2 small mammal species in pike stomach samples (Table 2).

\section{All prey}

Pike stomach contents differed among months (MANCOVA: Wilk's lambda $=0.78, F_{28,404}=1.89$, $P=0.004$ ) and by pike length (MANCOVA: $\left.F_{14,202}=4.72, P=<0.0001\right)$. Total Oncorhynchus were the dominant prey category by mass, the most frequently encountered prey item and the most numerous prey item in stomachs sampled in May, June and August (Table 2). We found up to 47, 14 and 8 Pacific salmonids/pike in May, June and August, respectively. The $\% M$ of Total Oncorhynchus did not differ among months (ANCOVA: $F_{2}=1.37$, 
Table 1. Sample size for pike stomach contents and fork length (FL) of sampled pike in the Deshka River in May, June and August 2011.

\begin{tabular}{|c|c|c|c|c|c|}
\hline Months & $\begin{array}{l}\text { Pike } \\
\text { sampled }\end{array}$ & $\begin{array}{l}\text { Empty } \\
\text { stomachs }\end{array}$ & $\begin{array}{l}\text { Stomachs } \\
\text { with } \\
\text { unidentifiable } \\
\text { contents }\end{array}$ & $\begin{array}{l}\text { FL range } \\
(\mathrm{cm})\end{array}$ & $\begin{array}{l}\text { Mean } \\
\mathrm{FL}(\mathrm{cm}) \\
\pm 1 \mathrm{SE}\end{array}$ \\
\hline May & 97 & 18 & 4 & $25.0-67.7$ & $40.9 \pm 1.6$ \\
\hline June & 99 & 10 & 3 & $24.7-65.0$ & $35.9 \pm 1.0$ \\
\hline August & 78 & 19 & 1 & $28.5-70.5$ & $45.0 \pm 1.0$ \\
\hline
\end{tabular}

$P=0.26)$, but it did differ by pike length (ANCOVA: $F_{1}=5.40, P<0.0001$ ). The $\% M$ of Total Oncorhynchus decreased with pike size $\left(r^{2}=0.16, P<0.0001\right)$.

A bivariate plot of prey-specific abundance versus $\% O$ indicated that Total Oncorhynchus was the dominant food category for pike in May, June and August (Fig. 2). PSA (33\%-58\%) and $O(32 \%-45 \%)$ for total Oncorhynchus exceeded all other prey taxa. In May, pike fed opportunistically on longnose suckers $(P S A=18 \%, O=6 \%)$ and generally on Arctic lam- prey $(P S A=4 \%, O=15 \%)$. In June, pike fed opportunistically on round whitefish $(P S A=25 \%$, $O=7 \%$ and generally on Arctic lamprey $(P S A=2 \%, O=11 \%)$. In August, pike fed opportunistically on round whitefish $(P S A=22 \%, O=7 \%)$ and voles $(P S A=17 \%, O=6 \%)$ (Fig. 2). All other prey taxa occurred infrequently and contributed little to consumed mass.

The number of pike captured ranged from 1 to 111 individuals per slough. The correlation between\%M of Total Oncorhynchus and pike relative abundance/ slough was not statistically significant $(R=0.30$, $P=0.32$ ), but the correlation between maximum prey size and pike length was $(R=0.58$, $P<0.0001)$. We found no difference in this latter correlation among seasons (ANCOVA: $F_{2}=1.14$, $P=0.32)$.

Pacific salmonids

Pike stomach samples of Oncorhynchus species differed among months (MANCOVA: Wilk's lambda $\left.=0.80, F_{10,422}=5.06, P<0.0001\right)$ and by

Table 2. Diet composition for pike sampled in the Deshka River in May, June and August 2011. Prey taxa are quantified by per cent number (\%N), mass $(\% \mathrm{M})$, and frequency of occurrence $(\% 0)$. Oncorhynchus spp. are prey that could only be identified to genus. Total Oncorhynchus is the sum value across all prey within the Oncorhynchus genus.

\begin{tabular}{|c|c|c|c|c|c|c|c|c|c|c|}
\hline \multirow[b]{2}{*}{ Diet item } & \multirow[b]{2}{*}{ Scientific name } & \multicolumn{3}{|l|}{ May } & \multicolumn{3}{|l|}{ June } & \multicolumn{3}{|c|}{ August } \\
\hline & & $\% \mathrm{~N}$ & $\% \mathrm{M}$ & $\% 0$ & $\% N$ & $\% \mathrm{M}$ & $\% 0$ & $\% N$ & $\% \mathrm{M}$ & $\% 0$ \\
\hline \multicolumn{11}{|l|}{ Invertebrates } \\
\hline Amphipods & Gammaridae & 0 & 0 & 0 & 0 & 0 & 0 & 0 & 0 & 0 \\
\hline Aquatic beetles & Dytiscidae & 0 & 0 & 0 & 0 & 0 & 0 & 0 & 0 & 0 \\
\hline Damselflies & Coenagrionidae & 3 & 2 & 3 & 0 & 0 & 0 & 0 & 0 & 0 \\
\hline Dragonflies & Aeshnidae & 1 & 1 & 2 & & 2 & 2 & 5 & 3 & 5 \\
\hline Leeches & Erpobdellidae spp. & 4 & 3 & 5 & 1 & 1 & 1 & 3 & 2 & 3 \\
\hline Mayflies & Siphlonuridae & 0 & 0 & 0 & 0 & 0 & 0 & 0 & 0 & 0 \\
\hline \multicolumn{11}{|l|}{ Salmonid fish } \\
\hline Arctic grayling & Thymallus arcticus & 1 & 1 & 1 & 0 & 1 & 1 & 0 & 0 & 0 \\
\hline Coho salmon & Oncorhynchus kisutch & 0 & 0 & 0 & 0 & 1 & 1 & 12 & 16 & 11 \\
\hline Chinook salmon & 0. tshawytscha & 24 & 30 & 20 & 41 & 42 & 36 & 20 & 18 & 20 \\
\hline Rainbow trout & 0. mykiss & 3 & 3 & 3 & 0 & 0 & 0 & 2 & 2 & 2 \\
\hline Round whitefish & Prosopium cylindraceum & 2 & 4 & 2 & 6 & 10 & 7 & 10 & 11 & 10 \\
\hline Sockeye salmon & O. nerka & 0 & 0 & 0 & 0 & 0 & 0 & 0 & 0 & 0 \\
\hline Oncorhynchus spp. & & 21 & 15 & 21 & 28 & 23 & 29 & 12 & 13 & 12 \\
\hline Total Oncorhynchus & & 48 & 48 & 45 & 70 & 67 & 65 & 46 & 48 & 43 \\
\hline \multicolumn{11}{|l|}{ Other fish } \\
\hline Arctic lamprey & Lampetra camtschatica & 12 & 8 & 13 & 8 & 7 & 9 & 2 & 2 & 2 \\
\hline Burbot & Lota lota & 1 & 1 & 1 & 0 & 1 & 1 & 7 & 7 & 7 \\
\hline Eulachon & Thaleichthys pacificus & 0 & 0 & 0 & 0 & 0 & 0 & 0 & 0 & 0 \\
\hline Longnose sucker & Catostomus catostomus & 6 & 8 & 8 & 0 & 0 & 0 & 7 & 0 & 7 \\
\hline 9-spine stickleback & Pungitius pungitius & 0 & 0 & 0 & 0 & 0 & 0 & 0 & 0 & 0 \\
\hline Northern pike & Esox lucius & 0 & 0 & 0 & 1 & 0 & 1 & 0 & 0 & 0 \\
\hline Slimy sculpin & Cottus cognatus & 6 & 6 & 6 & 6 & 6 & 6 & 2 & 2 & 2 \\
\hline 3-spine stickleback & Gasterosteus aculeatus & 14 & 16 & 14 & 2 & 2 & 3 & 11 & 9 & 10 \\
\hline \multicolumn{11}{|l|}{ Other } \\
\hline Red-backed voles & Myodes rutilus & 0 & 0 & 0 & 3 & 3 & 3 & 9 & 9 & 9 \\
\hline Shrews & Sorex spp. & 0 & 0 & 0 & 1 & 1 & 0 & 0 & 0 & 0 \\
\hline Wood frog & Rana sylvatica & 0 & 2 & 1 & 0 & 0 & 0 & 0 & 0 & 0 \\
\hline
\end{tabular}



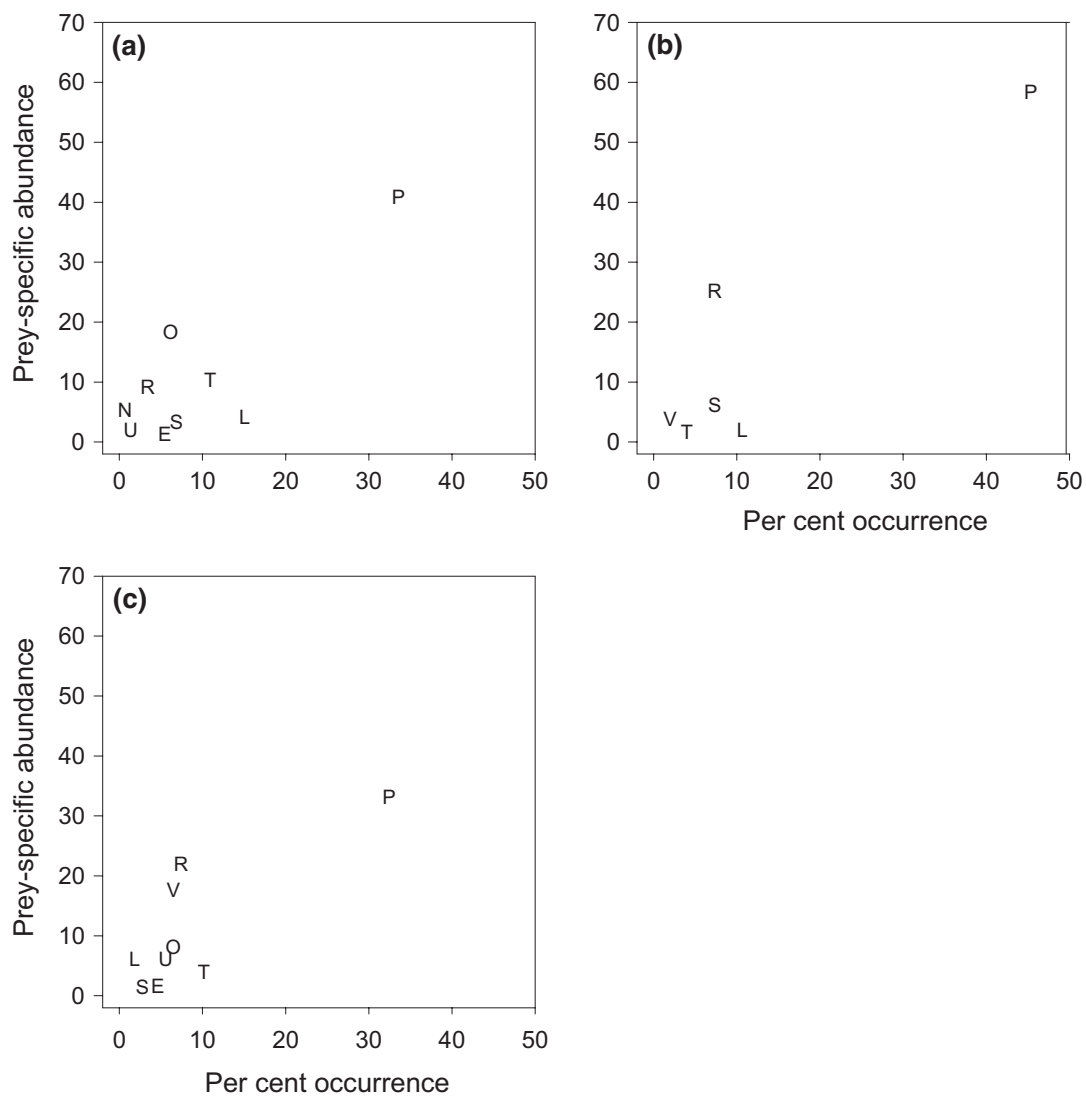

Fig. 2. Biplot representation of prey-specific abundance (per cent wet mass) versus per cent occurrence for all taxa in the Deshka River: Prey use by pike collected in (a) May, (b) June and (c) August. Letters correspond to individual prey taxa: E = Leech, L = Arctic lamprey, $\mathrm{N}=$ Northern pike, $\mathrm{O}=$ Longnose sucker, $\mathrm{P}=$ Pacific salmonids, $\mathrm{R}=$ Round whitefish, $\mathrm{S}=$ Slimy sculpin, $\mathrm{T}=\mathrm{Three}$-spine stickleback, $\mathrm{U}=$ Burbot and $\mathrm{V}=$ Vole. Prey that are not shown in the biplots had prey-specific abundance and occurrence values $<5 \%$.

pike length $\left(F_{5,211}=13.37, P<0.0001\right)$. In May, pike stomachs contained Chinook salmon, rainbow trout and unidentified Oncorhynchus spp., but\%M varied among species (Table 2; ANCOva: $F_{4}=22.31$, $P<0.0001)$. Chinook salmon represented the greatest proportion of the total diet mass, while rainbow trout represented the least (Tukey-HSD). We recorded a maximum of 33 Chinook salmon/pike and 1 rainbow trout/pike in May. In June and August, we observed Chinook salmon, rainbow trout, sockeye salmon and unidentified Oncorhynchus spp. in pike stomach samples (Table 2). The\% $M$ of these species varied in June (ANCOva: $F_{4}=49.25, \quad P<0.0001$ ) and August (ANCOVA: $\left.F_{4}=7.00, P<0.0001\right)$. In June, Chinook salmon represented the greatest proportion of the total mass $(M=42 \%)$ followed by unidentified Oncorhynchus spp. $(M=23 \%)$. We observed a maximum of 13 Chinook salmon/pike and 9 unidentified salmonids/ pike. Contributions of the remaining species were negligible. In August, Chinook salmon, coho salmon and unidentified Oncorhynchus spp. had similar $M$ (13-18\%), but $M$ values for rainbow trout and sockeye salmon were $<1 \%$ (Tukey-HSD). We observed a maximum of 5 Chinook salmon/pike and 5 coho salmon/pike.

There was no correlation between pike length and $\% M$ of coho salmon $\left(r^{2}=0.00, P=0.79\right)$ or sockeye salmon $\left(r^{2}=0.00, P=0.89\right)$. Pike length explained little of the variation in the\% $M$ of Chinook salmon, unidentified Oncorhynchus spp. and rainbow trout $\left(r^{2}=0.15, \quad P<0.0001 ; \quad r^{2}=0.03, \quad P=0.02 ; \quad\right.$ and $r^{2}=0.08, P<0.0001$, respectively).

The bivariate plot of $P S A$ versus $\% O$ indicated that Chinook salmon were the relatively dominant food item in May, June and August (PSA $=13-44 \%$, $O=21-33 \%$; Fig. 3). Coho salmon did not occur in pike stomach samples in May, were rare in June and had similar importance to Chinook salmon in August $(P S A=11 \%, O=14 \%$; Fig. 3). Pike fed opportunistically on rainbow trout in May $(P S A=15 \%$, $O=2 \%$ ) and rarely in August (Fig. 3). Rainbow trout were absent from stomach samples in June.

\section{Alexander Creek}

Pike sample size and lengths are reported in Table 3. Mean length of pike did not differ among reaches in 


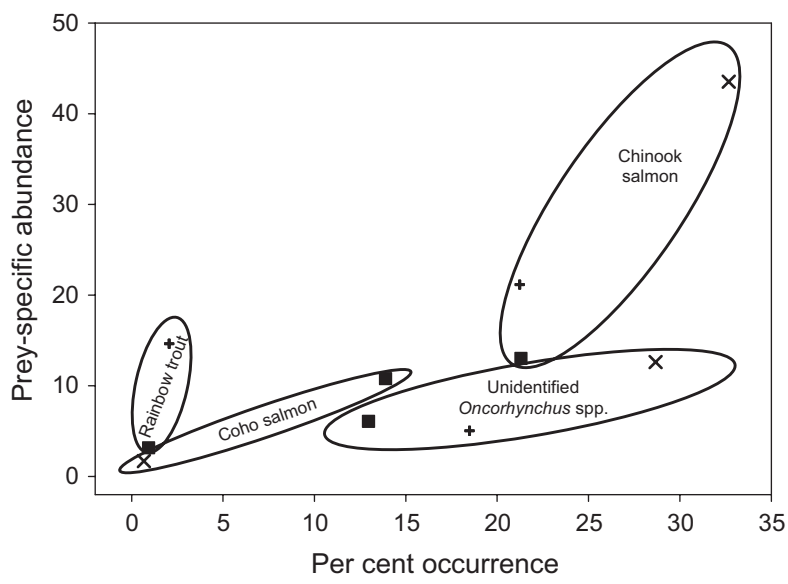

Fig. 3. Biplot representation of prey-specific abundance (per cent wet mass) versus per cent occurrence for Pacific salmonid species in the Deshka River. Symbols indicate the month in 2011 when pike diets were sampled: $(+)=$ May, $(\times)=$ June and $(\boldsymbol{\square})=$ August. The ellipses surround specific prey categories.

May, but pike in the upper reach in June were significantly smaller than pike sampled in May (ANOvA: $\left.F_{3,165}=35.13, P<0.0001\right)$. Pike stomach samples had 11 species of fish, 6 types of invertebrates, 1 anuran and 2 small mammal species (Table 3 ).

\section{All prey}

Pike stomach contents differed among reaches (MANCOVA: Wilk's lambda $=0.31, F_{42,449}=5.11$, $P<0.0001$ ), but contents were not related to pike length (MANCOVA: $F=0.14, \quad P=0.27$ ). Total Oncorhynchus was the relatively dominant prey category by mass $(31 \%)$ in the lower reach of Alexander Creek (Table 4; Ancova: $F_{13}=6.54, P<0.0001$ ). We observed a maximum of two Pacific salmonids/ pike in the lower reach.

In contrast, Total Oncorhynchus only occasionally occurred in pike diets in the middle reach, and it did not occur in diets in the upper reach in May or June. Rather, Arctic lamprey were the dominant prey item by mass $(34 \%)$ in the middle reach (Table 4; ANCOva: $F_{13}=8.20, P<0.0001$ ), and slimy sculpin were the dominant prey item by mass in the upper reach in May $(72 \%)$ and June (68\%; ANCOVA: $F_{13}=28.85$, $P<0.0001$ and $F_{13}=80.32, P<0.0001$ respectively). In May, we observed a maximum of 24
Arctic lamprey/pike in the middle reach and 14 slimy sculpin/pike. In June, we observed up to eight slimy sculpin/pike. Slimy sculpin\%M in the upper reach did not differ between May and June (Tukey HSD). Pike length was not associated with the dominant prey items by mass in any reach (ANCOVA: $F_{1}<2.48$, $P>0.12$ ). Other prey taxa that contributed to pike diet mass include Arctic grayling in the lower reach, Arctic grayling and Total Oncorhynchus in the middle reach, leeches in the upper reach in May and amphipods in the upper reach in June (Table 4).

A bivariate plot of $P S A$ versus $\% O$ suggested that Total Oncorhynchus was a relatively dominant food category found in pike stomachs in the lower reach in May $(P S A=28 \%, O=27 \%$; Fig. 4). Arctic grayling $(P S A=36 \%, O=11 \%)$ and round whitefish $(P S A=28 \%, O=2 \%)$ were important opportunistic prey. Pike fed generally on Arctic lamprey $(P S A=2 \%, O=21 \%)$. In the middle reach, there was no dominant prey category (Fig. 4). Pike fed opportunistically on Arctic grayling $(P S A=52 \%$, $O=12 \%$ ) and generally on Arctic lamprey $(P S A=7 \%, O=35 \%)$. In the upper reach in May, pike fed dominantly on slimy sculpin $(P S A=55 \%$, $O=63 \%$ ) and opportunistically on Arctic grayling $(P S A=35 \%, O=6 \%)$. In the upper reach in June, pike fed dominantly on slimy sculpin $(P S A=45 \%, \quad O=39 \%), \quad$ opportunistically on voles $(P S A=49 \%, O=7 \%)$ and generally on amphipods $(P S A=1 \%, O=42 \%)$. Contributions of the remaining species were negligible.

In May, there was some evidence that prey size increased with pike length, but this relationship differed among reaches (ANCOVA: $F_{1,2}=8.31$, $P=0.0004)$. The relationship was weak in the lower reach $(R=0.31, P=0.04)$, and correlation coefficients were somewhat greater in the middle and upper reaches (middle: $R=0.58, P<0.0001$; upper: $R=0.50, P=0.01)$. In June, the correlation between prey size and pike length was not statistically significant in any reach $(R=0.25, P=0.06)$.

Gill nets captured 24-277 pike/slough in the lower reach, 14-105 pike/slough in the middle reach and 39-163 pike/slough in the upper reach. In addition, we captured 7-16 pike in five sloughs in the upper reach in June. However, the correlations between

Table 3. Sample size for pike stomach contents and fork length (FL) of sampled pike in Alexander Creek in May and June 2011.

\begin{tabular}{|c|c|c|c|c|c|c|}
\hline Month & Reach & Pike sampled & Empty stomachs & $\begin{array}{l}\text { Stomachs with unidentifiable } \\
\text { contents }\end{array}$ & FL range $(\mathrm{cm})$ & $\begin{array}{l}\text { Mean FL (cm) } \\
\pm 1 \mathrm{SE}\end{array}$ \\
\hline \multirow[t]{3}{*}{ May } & Lower & 79 & 21 & 15 & $25.0-70.1$ & $48.4 \pm 1.4$ \\
\hline & Middle & 60 & 12 & 6 & $31.2-100.0$ & $47.2 \pm 1.8$ \\
\hline & Upper & 53 & 24 & 3 & $24.5-61.6$ & $42.5 \pm 2.1$ \\
\hline June & Upper & 63 & 7 & 7 & $24.2-53.9$ & $31.7 \pm 8.6$ \\
\hline
\end{tabular}


Adam J. Sepulveda et al.

Table 4. Diet composition for pike sampled from the lower, middle and upper reaches of Alexander Creek in May and June 2011. Prey taxa are quantified by per cent number $(\% \mathrm{~N})$, mass $(\% \mathrm{M})$, and frequency of occurrence $(\% 0)$. Oncorhynchus spp. are prey that could only be identified to genus. Total Oncorhynchus is the sum value across all prey within the Oncorhynchus genus.

\begin{tabular}{|c|c|c|c|c|c|c|c|c|c|c|c|c|}
\hline \multirow[b]{2}{*}{ Diet item } & \multicolumn{3}{|c|}{ Lower } & \multicolumn{3}{|c|}{ Middle } & \multicolumn{3}{|c|}{ Upper_May } & \multicolumn{3}{|c|}{ Upper_June } \\
\hline & $\% N$ & $\% M$ & $\% 0$ & $\% N$ & $\% M$ & $\% 0$ & $\% N$ & $\% M$ & $\% 0$ & $\% N$ & $\% \mathrm{M}$ & $\% 0$ \\
\hline \multicolumn{13}{|l|}{ Invertebrates } \\
\hline Amphipods & 0 & 0 & 0 & 0 & 0 & 0 & 0 & 0 & 0 & 23 & 10 & 20 \\
\hline Aquatic beetles & 7 & 7 & 7 & 1 & 1 & 3 & 2 & 0 & 3 & 2 & 2 & 3 \\
\hline Damselflies & 2 & 0 & 2 & 5 & 5 & 3 & 0 & 0 & 0 & 0 & 0 & 0 \\
\hline Dragonflies & 10 & 0 & 9 & 0 & 0 & 0 & 4 & 4 & 3 & 3 & 3 & 4 \\
\hline Leeches & 6 & 6 & 5 & 2 & 1 & 5 & 9 & 8 & 13 & 4 & 4 & 8 \\
\hline Mayflies & 0 & 0 & 0 & 0 & 0 & 0 & 0 & 0 & 0 & 1 & 1 & 2 \\
\hline \multicolumn{13}{|l|}{ Salmonid fish } \\
\hline Arctic grayling & 11 & 12 & 11 & 11 & 15 & 12 & 5 & 7 & 6 & 2 & 2 & 1 \\
\hline Coho salmon & 0 & 0 & 0 & 0 & 0 & 0 & 0 & 0 & 0 & 0 & 0 & 0 \\
\hline Chinook salmon & 2 & 2 & 2 & 2 & 2 & 1 & 0 & 0 & 0 & 0 & 0 & 0 \\
\hline Rainbow trout & 6 & 6 & 5 & 2 & 3 & 3 & 0 & 0 & 0 & 0 & 0 & 0 \\
\hline Round whitefish & 2 & 2 & 2 & 0 & 0 & 0 & 0 & 0 & 0 & 0 & 0 & 0 \\
\hline Sockeye salmon & 0 & 0 & 0 & 0 & 0 & 0 & 0 & 0 & 0 & 0 & 0 & 0 \\
\hline Oncorhynchus spp. & 20 & 22 & 20 & 7 & 8 & 8 & 0 & 0 & 0 & 0 & 0 & 0 \\
\hline Total Oncorhynchus & 28 & 31 & 27 & 11 & 14 & 12 & 0 & 0 & 0 & 0 & 0 & 0 \\
\hline \multicolumn{13}{|l|}{ Other fish } \\
\hline Arctic lamprey & 19 & 17 & 21 & 45 & 34 & 35 & 1 & 0 & 3 & 0 & 0 & 0 \\
\hline Burbot & 0 & 0 & 0 & 8 & 11 & 9 & 1 & 1 & 3 & 0 & 0 & 0 \\
\hline Eulachon & 0 & 0 & 0 & 0 & 1 & 1 & 0 & 0 & 0 & 0 & 0 & 0 \\
\hline Longnose sucker & 0 & 0 & 0 & 1 & 2 & 1 & 4 & 4 & 3 & 0 & 0 & 0 \\
\hline 9-spine stickleback & 1 & 3 & 4 & 0 & 0 & 0 & 4 & 4 & 3 & 0 & 0 & 0 \\
\hline Northern pike & 0 & 0 & 0 & 0 & 0 & 0 & 0 & 0 & 0 & 0 & 0 & 0 \\
\hline Slimy sculpin & 8 & 9 & 9 & 8 & 8 & 12 & 71 & 72 & 68 & 60 & 71 & 60 \\
\hline 3-spine stickleback & 0 & 0 & 0 & 7 & 8 & 6 & 0 & 0 & 0 & 0 & 0 & 0 \\
\hline \multicolumn{13}{|l|}{ Other } \\
\hline Red-backed voles & 0 & 0 & 0 & 0 & 0 & 0 & 0 & 0 & 0 & 5 & 7 & 5 \\
\hline Shrews & 0 & 0 & 0 & 0 & 0 & 0 & 0 & 0 & 0 & 0 & 0 & 1 \\
\hline Wood frog & 5 & 5 & 4 & 0 & 1 & 1 & 0 & 0 & 0 & 0 & 0 & 0 \\
\hline
\end{tabular}

pike abundance and $\% M$ of any of the dominant prey taxa for these reaches were not statistically significant: Total Oncorhynchus in the lower reach $(R=-0.20, P=0.70)$, Arctic lamprey in the middle reach $(R=0.73, P=0.06)$ and slimy sculpin in May and in June in the upper reach (May: $R=0.40$, $P=0.51$; June: $R=-0.31, P=0.55)$.

\section{Pacific salmonids}

The proportion of Oncorhynchus species occurring in pike stomachs differed among reaches (MANCOVA: Wilk's lambda $\left.=0.83, F_{9,394}=3.58, P=0.0003\right)$, but not by pike length $\left(F_{3,162}=1.48, P=0.22\right)$. Chinook salmon, rainbow trout and unidentified Oncorhynchus spp. were the only Oncorhynchus species that we found in stomach samples and we did not find any of these species in stomachs sampled from the upper reach in May or June (Table 4). The\%M for each of these species did not differ among reaches (ANCOVA: $\quad F_{3}=0.16, \quad P=0.92 \quad$ and $\quad F_{3}=1.10$, $P=0.35)$ and $\% M$ was not related to pike length in any reach (AnCova: $F_{1}<2.05, P>0.15$ ). The $\% M$ for unidentified Oncorhynchus spp. differed among reaches (AnCova: $F_{3}=9.08, P<0.0001$ ) $-\% M$ in the lower reach was greater than the middle reach and the middle reach did not differ from the upper reach in May or June. We also found that $\% M$ for unidentified Oncorhynchus spp. was not related to pike length (ANCOVA: $F_{1}=2.45, P=0.12$ ).

A bivariate plot of $P S A$ versus $\% O$ indicated that pike fed opportunistically on rainbow trout in the lower reach $(P S A=21 \%, O=5 \%)$ and the contribution of Chinook salmon was negligible in the lower and middle reaches (Fig. 5). Pike fed generally on unidentified Oncorhynchus spp. in the lower reach $(P S A=6 \%, O=20 \%)$, but the contribution of this prey item was negligible in the middle reach (Fig. 5).

\section{Discussion}

We found that salmonids constitute the major prey items for pike in the Deshka River and in the lower reach of Alexander Creek throughout the summer. In the Deshka River, salmonids were dominant prey 

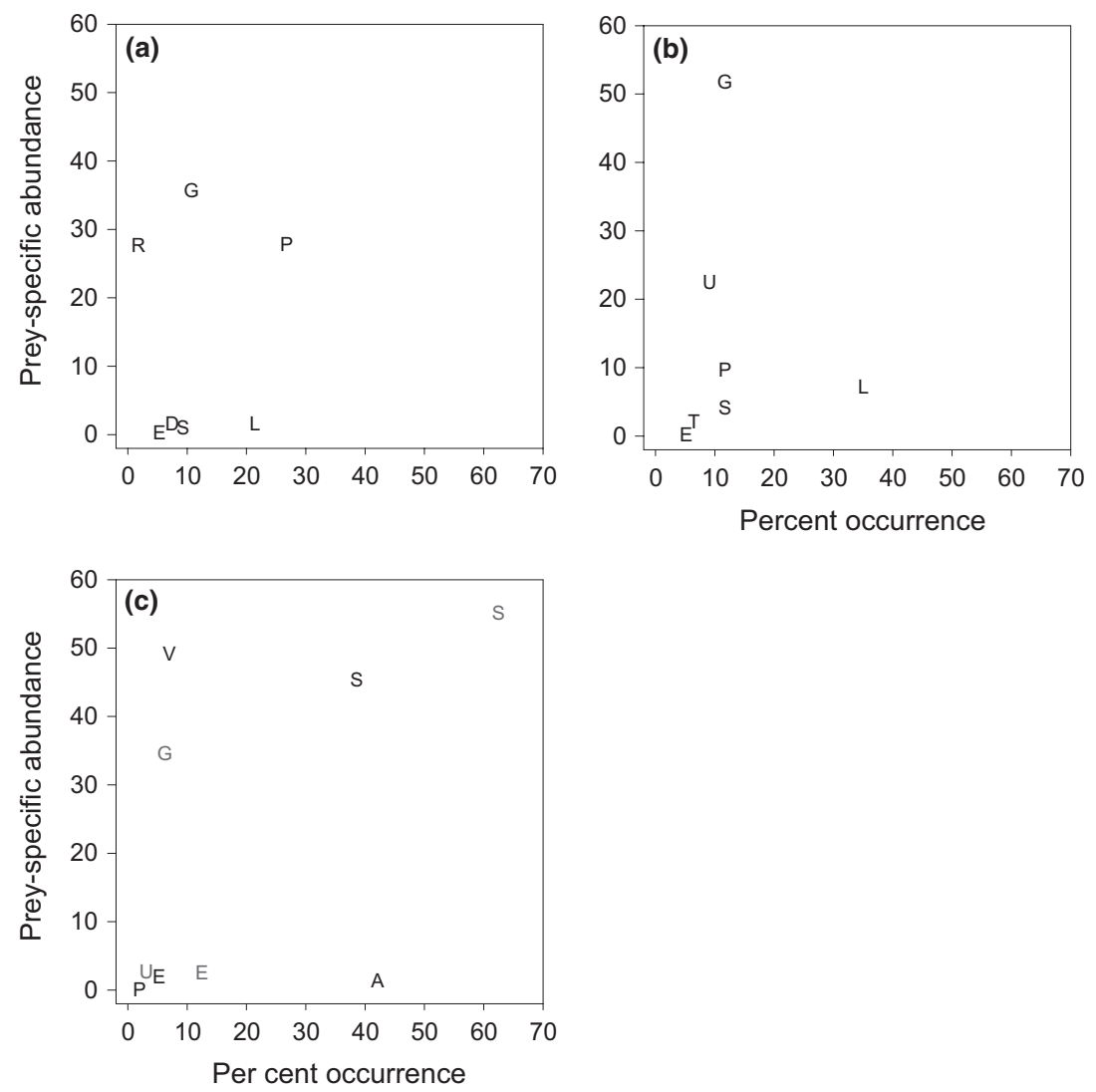

Fig. 4. Biplot representation of prey-specific abundance (per cent wet mass) versus per cent occurrence in Alexander Creek: Prey use by pike collected in (a) the lower reach in May, (b) the middle reach in May and (c) the upper reach in May (red letters) and June (black letters). Letters correspond to individual prey taxa: $\mathrm{A}=$ Amphipod, $\mathrm{B}=$ Aquatic beetle, $\mathrm{D}=$ Dragon fly, $\mathrm{E}=\mathrm{Leech}, \mathrm{G}=\mathrm{Arctic}$ grayling, $\mathrm{L}=$ Arctic lamprey, $\mathrm{P}=$ Pacific salmonids, $\mathrm{R}=$ Round whitefish, $\mathrm{S}=$ Slimy sculpin, $\mathrm{T}=$ Three-spine stickleback, $\mathrm{U}=\mathrm{Burbot}$ and $\mathrm{V}=$ Voles. Prey that are not shown in the biplots had prey-specific abundance and occurrence values $<5 \%$.

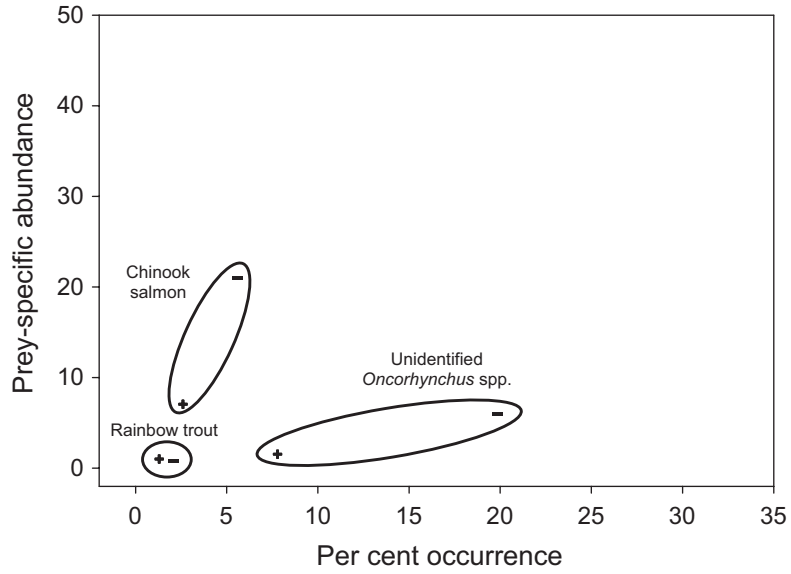

Fig. 5. Biplot representation of prey-specific abundance (per cent wet mass) versus per cent occurrence for Pacific salmonid species in Alexander Creek. Symbols indicate the reach in 2011 where pike diets were sampled: $(-)=$ lower and $(+)=$ middle. The ellipses surround specific prey categories.

items for pike and diet was not related to pike density. In Alexander Creek, salmonids were also frequently consumed by pike, even though salmonid abundance was low. We also found that the effects of pike invasions may extend beyond salmonids because pike shifted to consumption of other native fish, like slimy sculpin and Arctic lamprey, when salmonids were rare. Implications of this trophic adaptability are that invasive pike can drive multiple species to low abundance and possible extirpation (Byström et al. 2007; Haught \& von Hippel 2011).

We observed Pacific salmonids in 140 of the 274 pike stomachs sampled in the Deshka River and found that they were the dominant prey. Pike consumed $>600$ Pacific salmonids, the majority of which were Chinook salmon juveniles $(<100 \mathrm{~mm})$ in May and June and coho salmon juveniles $(<100 \mathrm{~mm})$ in August. Rainbow trout were rare in pike diets, but their PSA was high relative to their\%O because larger rainbow trout $(>150 \mathrm{~mm})$ were consumed. If our snapshots of pike stomach contents are indicative of daily consumption patterns, then extrapolation of our data suggests that pike consume a large proportion of recruiting salmonids. This extrapolation is supported by other studies - Kekäläinen et al. (2008) found that pike ate $29 \%$ of stocked Atlantic salmon (Salmo salar) smolts and Jepsen et al. (1998) estimated that 
pike were responsible for $56 \%$ of Atlantic salmon smolt mortality during a 3 week period. The ability for salmon to coexist with invasive pike comes into question when consumption and predation levels are this high.

In fact, Spens \& Ball (2008) found that pike and salmon coexistence is rare in Swedish boreal lakes and that self-sustaining salmon populations were only possible if pike were removed. However, their 'pikesalmonid noncoexistence rule' does not seem to apply to the Deshka River, where species like Chinook salmon have remained near Sustainable Escapement goals in the Deshka River despite the intensity of pike predation on salmonids that we observed. Understanding the mechanisms that allow for this incongruity may help managers with limited resources to prioritise habitats for pike suppression.

One aspect that may facilitate coexistence is spatial refugia. In other Alaskan systems where pike are native and are found with nondeclining salmon populations, such as the Wood River Lake system that flows into Bristol Bay, there is evidence of habitat segregation. Sockeye salmon in the Wood River Lake system are largely pelagic foragers and spend little time near the vegetated banks where pike are found (Chihuly 1976). Similarly, Chinook salmon spawn and rear in the middle and upper sections of the Deshka River, where there are large cobbles, deep water and riffles. Spawning and rearing habitat for pike is primarily found in sloughs in the lower section of the Deshka River, so there is minimal habitat overlap. Pike predation on juvenile salmon may be limited to these lower reaches for much of the year and to short, temporal windows when salmon smolts from upper reaches move downstream. The Alexander Creek drainage is the opposite; it has thousands of square kilometres of pike spawning and rearing habitat, and habitat that is restricted to Chinook salmon is rare. These observations suggest that the effects of predation by introduced pike on juvenile salmonids are strongly mediated by the physical template of habitat (Warren \& Liss 1980).

We could not test the hypothesis that pike are responsible for Pacific salmonid declines in Alexander Creek. However, we did find that Pacific salmonids were a relatively dominant prey item in the lower and middle reaches and that they were absent from stomach samples in the upper reach. This absence contrasts with historical spawning survey data in Alexander Creek, which found that $\approx 3600$ Chinook salmon adults returned annually and most of these fish spawned in the upper reaches (Yanusz \& Rutz 2009). More recent survey data show the opposite pattern and align with our stomach content data; there were 110 returning adults and spawning frequency declined with proximity to Alexander Lake where there are estimated to be $>13,000$ pike (36 fish/hectare; Oslund \& Ivey 2010; Rutz 1999; Yanusz \& Rutz 2009). In comparison, estimated pike densities are 1.78 fish/ha (Roach 1996) and 1.39 fish/ha (Dye 2002) in other Alaskan waters where pike are native and occur with salmon. Pike populations downstream of the lake are also abundant; ADFG removed $>4000$ pike from 60 side-sloughs of Alexander Creek in May and June 2011 (ADFG, unpublished data). Pike can achieve high abundance and densities in Alexander Creek because there is ample spawning and nursery habitat. When pike are abundant, our data suggest that they can have negative effects on salmon: individual pike consumed $>40$ salmonids per sampling event, $>73 \%$ of individuals had nonempty stomachs and diet was independent of pike density.

Pike prefer salmonid prey in the Susitna River basin (Rutz 1999) and once salmonids decline, pike predation pressure shifts to other taxa (Haught \& von Hippel 2011). In general, diet plasticity allows predator population size to be independent of the abundance of their preferred prey. As a result, predator encounter rates with preferred prey can remain high, even after preferred prey have declined (Fagan et al. 2002; Symondson et al. 2002). Not surprisingly, diet plasticity is a characteristic of many invasive predators that have been implicated in native species extinctions (e.g., Ogutu-Ohwayo 1993; Caut et al. 2008). Pike in Alexander Creek fit this theory. First, we found that pike have catholic diets. They fed on $>20$ different taxa and nonsalmonid prey dominated their stomach contents in reaches were spawning salmon are now rare. Specifically, pike stomach contents were dominated by slimy sculpin in the upper reach and Arctic lamprey in the middle reach. Second, pike abundance in Alexander Lake and Alexander Creek is high even though salmonids have declined. Third, we found salmonids in pike stomach contents in the middle and lower reaches despite the low abundance of salmonids. We did not link pike to any native species extinctions, but pike have been associated with the local extinction of multiple fish species in other systems (e.g., Patankar et al. 2006; Byström et al. 2007; Spens \& Ball 2008).

\section{Future directions}

Suppressing pike in systems where habitat is not limiting, like Alexander Creek, may be essential for salmonids and other native fish to recover to desired escapement goals. Indeed, pike eradication was required for self-sustaining salmon populations in Sweden (Spens \& Ball 2008). However, complete 
removal of pike in tributaries to the Susitna River basin will be difficult because this basin is extensive $\left(52,000 \mathrm{~km}^{2}\right)$ and remote. Moreover, pike occur in the main stem of the Susitna River and reinvasion is likely. Thus, managers must identify strategies to reduce the negative effects of pike on salmon populations.

Our diet data in the Deshka River suggest that removal of pike $<400 \mathrm{~mm}$ could help reduce predation on Pacific salmonids. We found that small pike consumed more Chinook and coho salmon biomass than large pike in the Deshka River. Most of these salmonids were $<100 \mathrm{~mm}$. The weak correlation between prey length and pike size indicates that large pike also consumed small prey, like Arctic lamprey and insects, but small salmonids were rare in their diet. ADFG managers have been aware that small pike consume a disproportionate number of juvenile salmonids (Rutz 1999). In 1998, they implemented slot limits in Alexander Lake that allowed for unlimited take of pike $<558 \mathrm{~mm}$ and limited the take of pike $\geq 558 \mathrm{~mm}$. The rationale was that large pike can limit the abundance of small pike through cannibalism and that most anglers will only travel to fish for pike if they can keep large fish (Yanusz \& Rutz 2009). Angling pressure was minimal in this remote drainage, so slot limits had little effect on small pike abundance (Yanusz \& Rutz 2009). We also found that pike cannibalism was rare in Alexander Creek. Additional tools that are effective at suppressing small pike, as well as larger pike, in remote areas are needed in Southcentral Alaska.

Our stomach content data confirm that juvenile salmonids are the major prey item for invasive pike in systems where salmonids are still abundant, but that pike will feed on alternative prey after salmonids have declined. Thus, invasive pike are a threat to the ecosystem structure and function of many streams in Southcentral Alaska, especially in systems where pike spawning and rearing habitat are not limited. We believe that actions that limit the spread of pike to new drainages and that suppress pike populations in invaded drainages will benefit salmonids and other native species.

\section{Acknowledgements}

This study was funded by the Alaska Sustainable Salmon Fund (Project \# 44609). We thank Alaska Department Fish \& Game's Division of Commercial Fisheries (Soldotna, AK) and Division of Sport Fisheries (Palmer, AK) and Bob Pence (Alaska Pike Hunters) for providing logistical and technical support in the field. We thank Joshua Bishoff, Adrian Baer, Kasaan Brandel, Kiche Brandel, Eric Hollerback, Don Reeves and Matt Warnke for help in the field. We also thank Erik Schoen and Bob Gresswell for helpful comments on the manuscript. Any use of trade, product or firm names is for descriptive purposes only and does not imply endorsement by the U.S. Government.

\section{References}

Albins, M.A. \& Hixon, M.A. 2008. Invasive Indo-Pacific lionfish Pterois volitans reduce recruitment of Atlantic coral-reef fishes. Marine Ecology Progress Series 367: 233-238.

Amundsen, P.A., Gabler, H.M. \& Staldvik, F. 1996. A new approach to graphical analysis of feeding strategy from stomach contents data-modification of the Costello (1990) method. Journal of Fish Biology 48: 607-614.

Baxter, C.V., Fausch, K.D., Murakami, M. \& Chapman, P.L. 2004. Fish invasion restructures stream and forest food webs by interrupting reciprocal prey subsidies. Ecology 85: 26562663.

Byström, P., Karlsson, J., Nilsson, P., Van Kooten, T., Ask, J. \& Olofsson, F. 2007. Substitution of top predators: effects of pike invasion in a subarctic lake. Freshwater Biology 52: 1271-1280.

Casselman, J.M. \& Lewis, C.A. 1996. Habitat requirements of northern pike (Essox lucius). Canadian Journal of Fisheries and Aquatic Sciences 53: 161-174.

Caut, S., Angulo, E. \& Courchamp, F. 2008. Dietary shift of an invasive predator: rats, seabirds and sea turtles. Journal of Applied Ecology 45: 428-437.

Cederholm, C.J., Kunze, M.D., Murota, T. \& Sibatani, A. 1999. Pacific salmon carcasses: essential contributions of nutrients and energy for aquatic and terrestrial ecosystems. Fisheries 24: 6-15.

Chihuly, M. 1976. Biology of northern pike (Esox lucius) in the Wood River Lake system Bristol Bay, Alaska. MS Thesis. Fairbanks: University of Alaska. 1-111 pp.

Chipps, S.R. \& Garvey, J.E. 2007. Quantitative assessment of food habits and feeding patterns. In: Guy, C. \& M. L. Brown (eds). Analysis and interpretation of freshwater fisheries data. Maryland, USA: American Fisheries Society. 473-514 pp.

Dye, J.E, Wallendorf, M., Naughton, G. P. \& Gryska, A. D. 2002. Stock Assessment of Northern Pike in Lake Aleknagik, 1998-1999. Anchorage: Alaska Dept. of Fish and Game, Division of Sport Fish, Research and Technical Services. 1-9 pp.

Eklöv, P. \& Hamrin, S.F. 1989. Predatory efficiency and prey selection: interactions between pike Esox lucius, perch Perca fluviatilis and rudd Scardinus erythrophthalmus. Oikos: 56: 149-156.

Fagan, W.F., Lewis, M.A., Neubert, M.G. \& Van Den Driessche, P. 2002. Invasion theory and biological control. Ecology Letters 5: 148-157.

Haught, S. \& von Hippel, F.A. 2011. Invasive pike establishment in Cook Inlet Basin lakes, Alaska: diet, native fish abundance and lake environment. Biological Invasions 13: 2103-2114.

Jepsen, N., Aarestrup, K., Økland, F. \& Rasmussen, G. 1998. Survival of radiotagged Atlantic salmon (Salmo salar L.)and trout (Salmo trutta L.) smolts passing a reservoir during seaward migration. Hydrobiologia 371: 347-353. 
Adam J. Sepulveda et al.

Johnson, B.M., Martinez, P.J., Hawkins, J.A. \& Bestgen, K.R. 2008. Ranking predatory threats by nonnative fishes in the Yampa River, Colorado, via bioenergetics modeling. North American Journal of Fisheries Management 28: 1941-1953.

Kekäläinen, J., Niva, T. \& Huuskonen, H. 2008. Pike predation on hatchery-reared Atlantic salmon smolts in a northern Baltic river. Ecology of Freshwater Fish 17: 100-109.

Mills, M.J. 1986. Alaska statewide sport fish harvest studies1985 data. Alaska Department of Fish and Game, Federal Aid in Fish Restoration and Anadromous Fish Studies. Annual Performance Report 1985-1986. Project F-10-1, 27 (RT-2), Juneau. Available at: http://www. sf. adfg. state. ak. us/ FedAidPDFs/ f-10-1 (27) RT-2. pdf.

Nilsson, P.A. 2001. Predator behaviour and prey density: evaluating density-dependent intraspecific interactions on predator functional responses. Journal of Animal Ecology 70: 14-19.

Nilsson, P.A. \& Brönmark, C. 1999. Foraging among cannibals and kleptoparasites: effects of prey size on pike behavior. Behavioral Ecology 10: 557.

Nilsson, P.A. \& Brönmark, C. 2000. Prey vulnerability to a gape-size limited predator: behavioural and morphological impacts on northern pike piscivory. Oikos 88: 539-546.

Ogutu-Ohwayo, R. 1990. The decline of the native fishes of lakes Victoria and Kyoga (East Africa) and the impact of introduced species, especially the Nile perch, Lates niloticus, and the Nile tilapia, Oreochromis niloticus. Environmental Biology of Fishes 27: 81-96.

Ogutu-Ohwayo, R. 1993. The effects of predation by Nile perch, Lates niloticus L., on the fish of Lake Nabugabo, with suggestions for conservation of endangered endemic cichlids. Conservation Biology 7: 701-711.

Oslund, S. \& Ivey, S. 2010. Recreational Fisheries of Northern Cook Inlet, 2009-2010: report to the Alaska Board of Fisheries, February 2011. Alaska Department of Fish \& Game Fishery Management Report. Anchorage, 1-161.
Patankar, R., Von Hippel, F. \& Bell, M. 2006. Extinction of a weakly armoured threespine stickleback (Gasterosteus aculeatus) population in Prator Lake, Alaska. Ecology of Freshwater Fish 15: 482-487.

Roach, S.M. 1996. Abundance and Composition of the Northern Pike Population in Harding Lake, 1996. Alaska Dept. of Fish and Game, Division of Sport Fish Fairbanks, 1-25.

Rutz, D. 1999. Movements, food availability and stomach contents of northern pike in selected Susitna River drainages, 1996-1997. Alaska Department of Fish and Game, Fishery Data Series. Anchorage, 1-68.

Spens, J. \& Ball, J.P. 2008. Salmonid or nonsalmonid lakes: predicting the fate of northern boreal fish communities with hierarchical filters relating to a keystone piscivore. Canadian Journal of Fisheries and Aquatic Sciences 65: 1945-1955.

Symondson, W., Sunderland, K. \& Greenstone, M. 2002. Can generalist predators be effective biocontrol agents? 1. Annual Review of Entomology 47: 561-594.

Vander Zanden, M.J., Casselman, J.M. \& Rasmussen, J.B. 1999. Stable isotope evidence for the food web consequences of species invasions in lakes. Nature 401: 464467.

Warren, C.E. \& Liss, W.J. 1980. Adaptation to aquatic environments. In: Lackey, R.T. \& Nielson, L., eds. Fisheries management. Blackwell Scientific Publications, Oxford, UK. pp. 15-40.

Whitmore, C. \& Sweet, D. 1998. Area management report for the recreational fisheries of Northern Cook Inlet, 1997. Alaska Department of Fish \& Game, Division of Sport Fish. Anchorage, 1-291.

Yanusz, R. \& Rutz, D. 2009. Alexander Creek/Lake White Paper. Alaska Department of Fish and Game, Fishery Data Series. Palmer, 1-6. 